1990

\title{
The Interpretation of International Maritime Conventions in United States Law
}

\author{
Mark Weston Janis \\ University of Connecticut School of Law
}

Follow this and additional works at: https://opencommons.uconn.edu/law_papers

Part of the Admiralty Commons, Constitutional Law Commons, and the International Law Commons

\section{Recommended Citation}

Janis, Mark Weston, "The Interpretation of International Maritime Conventions in United States Law" (1990). Faculty Articles and Papers. 196.

https://opencommons.uconn.edu/law_papers/196 


\section{HEINONLINE}

Citation: 38 Am. J. Comp. L. Supp. 3411990

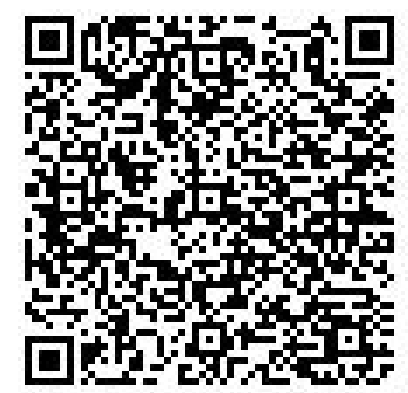

Content downloaded/printed from

HeinOnline (http://heinonline.org)

Mon Aug 15 17:59:18 2016

-- Your use of this HeinOnline PDF indicates your acceptance of HeinOnline's Terms and Conditions of the license agreement available at http://heinonline.org/HOL/License

-- The search text of this PDF is generated from uncorrected OCR text.

-- To obtain permission to use this article beyond the scope of your HeinOnline license, please use:

https://www.copyright.com/ccc/basicSearch.do?

\&operation $=$ go\&search $T y p e=0$

\&lastSearch $=$ simple\&all=on\&titleOrStdNo=0002-919X 
TOPIC III.D.1.

\author{
MARK W. JANIS
}

\title{
The Interpretation of International Maritime Conventions in United States Law
}

In the United States, the interpretation of international maritime conventions is carried out within the general context of U.S. constitutional law. The Constitution's Article II(2) provides that the President of the United States is granted the "Power, by and with the Advice and Consent of the Senate, to make Treaties, provided two-thirds of the Senators present concur." Article III(2) extends the judicial power of the United States "to all Cases, in Law and Equity, arising under this Constitution, the Laws of the United States, and Treaties made, or which shall be made, under their Authority." Article VI(2) instructs that the "Constitution, and the Laws of the United States which shall be made in Pursuance thereof; and all Treaties made, or which shall be made, under the Authority of the United States, shall be the supreme Law of the Land; and the Judges in every State shall be bound thereby, any Thing in the Constitution or Laws of any State to the Contrary notwithstanding." Article I(10) limits the States: "No State shall enter into any Treaty, Alliance, or Confederation."1

In U.S. constitutional law, treaties need not be implemented by statutory enactment if the treaty or provision in question is deemed to be self-executing. This rule was first set forth in 1829 in Foster \& Elam v. Neilson by Chief Justice John Marshall:

A treaty is in its nature a contract between two nations, not a legislative act. It does not generally effect, of itself, the object to be accomplished, especially so far as its operation is infra-territorial; but is carried into execution by the sovereign power of the respective parties to the instrument.

In the United States a different principle is established. Our constitution declares a treaty to be the law of the land.

MaRK W. JANIS is Professor of Law, University of Connecticut. Peter Morgan and John Fitzpatrick assisted in the preparation of this report.

1. See M.W. Janis, An Introduction to International Law $72-80$ (1988) [hereinafter cited as "Janis"]; American Law Institute, Restatement of the Law Third, The Foreign Relations Law of the United States 41 (1987) [hereinafter cited as "Restatement"]. 
It is, consequently, to be regarded in courts of justice as equivalent to an act of the legislature, whenever it operates of itself without the aid of any legislative provision. But when the terms of the stipulation import a contract, when either of the parties engages to perform a particular act, the treaty addresses itself to the political, not the judicial department; and the legislature must execute the contract before it can become a rule for the Court. ${ }^{2}$

"The question whether a treaty is self-executing is a matter of interpretation for the courts when the issue presents itself in litigation."3 The difficulty of this enquiry is well-illustrated by United States v. Postal, where the U.S. Fifth Circuit Court of Appeal held that Article 6 of the 1958 Convention on the High Seas was not selfexecuting:

Article 6 declares the exclusivity of a nation's jurisdiction over the vessels entitled to fly its flag: "Ships shall sail under the flag of one State only and, save in exceptional cases expressly provided for in international treaties or in these articles, shall be subject to its exclusive jurisdiction on the high seas." On its face, this language would bear a self-executing construction because it purports to preclude the exercise of jurisdiction by foreign states in the absence of an exception embodied in treaty. We are admonished, however, to interpret treaties in the context of their promulgation, and we think the context of article 6 compels the conclusion that it is not self-executing. ${ }^{4}$

The Court reached this conclusion by first recognizing the "lack of mutuality between the United States and countries that do not recognize treaties as self-executing."5 It then reviewed continuing U.S. practice asserting "limited jurisdiction over vessels on the high seas, generally but not always within the twelve-mile limit, to enforce a variety of interests not expressly authorized in treaties."6 Finally, it concluded that it was not "the intent of the United States to so limit the operation of its statutes" because of the legislative history of the convention.?

That such a determination that an international maritime convention or its provision is or is not self-executing may be a matter of considerable judicial discretion is demonstrated by the criticism lev-

2. 27 U.S. (2 Peters) 253, 314 (1829).

3. United States v. Postal, 589 F.2d 862, 876 (5th Cir. 1979), cert. denied 444 U.S. 832 (1979).
4. Id. at $877-78$.
5. Id. at 878 .
6. Id. at $879-81$.
7. Id. at $\mathbf{8 8 1 - 8 8 4}$. 
elled at the Postal holding. ${ }^{8}$ The First Circuit has even gone so far as to hold that Article 6 of the High Seas Convention is part of customary international law and so therefore part of U.S. law. ${ }^{9}$

Insofar as international maritime conventions have been enacted into U.S. law by Congressional act they are typically construed as statutes with little judicial mention made of the treaty. So, for example, though "much of the law of salvage is governed by the Salvage Convention of 1910 , to which the United States is a party . . . the convention generally restates American salvage law, and several of its provisions are also found in the Salvage Act [and] the convention is rarely cited by American courts." 10 The international conventions relating to the rules of the road on the high seas have been likewise promulgated by statute in the United States, it being more or less assumed that "practically identical Rules have been enacted by the other maritime nations."11 Similarly, the United States has passed legislation fulfilling many of its obligations under international maritime conventions relating to shipping, e.g., the regulation of pilots, load lines, qualifications and wages of officers and crews of vessels, carriage of dangerous goods, and ocean dumping. ${ }^{12} \mathrm{~A}$ very useful survey of the statutory implementation of international maritime conventions in the United States is to be found in a recent study by the Maritime Law Association of the United States. ${ }^{13}$

When an international maritime convention is held to be selfexecuting or when the courts have decided that the intent of Congress or the President has been to comply with international law, the U.S. courts may turn to international practice and opinion to interpret these international obligations of the United States. The best-known expression of this principle appeared in a maritime case, albeit one involving the customary law of the sea. In the Paquete Habana, the U.S. Supreme Court overturned the Navy's seizure of two Cuban fishing vessels captured during the Spanish-American War. ${ }^{14}$ Recording the proclamations of President McKinley to conduct the war "upon principles in harmony with the present views of nations and sanctioned by their recent practice" and to maintain a blockade of Cuba "in pursuance of . . the law of nations,"15 Justice

8. See the discussion in United States v. Green, 671 F.2d 46, 50 (1st Cir. 1982), (cert. denied, 457 U.S. 1135 (1982).)

9. United States v. Hensel, 699 F.2d 18, 27 (1st Cir. 1983).

10. F. Maraist, Admiralty 123 (2d ed. 1988).

11. G. Gilmore and C. Black, The Law of Admiralty 489 (2nd ed. 1975).

12. L.B. Sohn and K. Gustafson, The Law of the Sea 16-17 (1984).

13. "Answers of the Maritime Law Association of the United States to the Comité Maritime International's Questionnaire on Implementation of International Conventions," 18 Journal of Maritime Law and Commerce 589 (1987).

14. 175 U.S. 677 (1900).

15. Id. at 712 . 
Gray held that "International Law is part of our law, and must be ascertained and administered by the courts of justice of appropriate jurisdiction, as often as questions of right depending upon it are duly presented for their determination." 16

The 1980 Vienna Convention on the Law of Treaties ${ }^{17}$ is not in force for the United States. However, the U.S. Department of State has recognized the Convention as "the authoritative guide to current treaty law and practice."18 Similarly, the Restatement of the Foreign Relations Law of the United States (Third) "accepts the Vienna Convention as, in general, constituting a codification of the customary international law governing international agreements."19 The Restatement section 325 on "Interpretation of International Agreement" follows Article 31(1) and Article 31(3) of the Vienna Convention:

(1) An international agreement is to be interpreted in good faith in accordance with the ordinary meaning to be given to its terms in their context and in the light of its object and purpose.

(2) Any subsequent agreement between the parties regarding the interpretation of the agreement, and subsequent practice between the parties in the application of the agreement, are to be taken into account in its interpretation..$^{20}$

In the United States, many courts strive to give treaties the same interpretation they would have before an international court. However, there is sometimes a greater willingness shown in the United States than internationally to interpret a treaty by ascertaining the meaning intended by the parties rather than by strictly reading the text. A U.S. court or agency may well use interpretative materials supplementary to those relied on by an international court such as Congressional reports and debates and other internal documentation relating to the negotiation or ratification of an international agreement.21

Although courts in the United States have the competence to finally interpret treaties for domestic law purposes, great judicial deference is usually paid to the Executive Branch, which "has authority to determine the interpretation of an international agreement to be asserted by the United States in its relations with other states."22

16. Id. at 700.

17. U.N. Doc. A/CONF. 39/27 (1969), reprinted in $63 \mathrm{Am}$. J. Int Z. L. 875 (1969).

18. S. Exec. Doc. L., 92d Cong., 1st sess., at 1 (1971).

19. Restatement supra note 1 , at 145 ; Janis, supra note 1 , at 15 .

20. Restatement, supra note 1 , at 196.

21. Restatement, supra note 1 , at 200-201.

22. Id. at 202. 
For example, in Sumitomo Shoji America, Inc. v. Avagliano, the Supreme Court decided to follow the interpretation of a treaty as it was made by both the U.S. and Japanese governments and held that "[a]lthough not conclusive, the meaning attributed to treaty provisions by the Government agencies charged with their negotiation and enforcement is entitled to great weight."23

In interpreting international conventions, the U.S. courts look both at the explicit terms of the treaty and at the intent of the parties: "The clear import of treaty language controls unless 'application of the words of the treaty according to their obvious meaning effects a result inconsistent with the intent or expectations of its signatories." "24 The rule relating to the role of the courts was plainly set forth in 1821 in an opinion by Justice Story of the Supreme Court:

[T]o alter, ' amend, or add to any treaty, by inserting any clause, whether small or great, important or trivial, would be, on our part, an usurpation of power, and not an exercise of judicial functions. It would be to make, and not to construe a treaty. Neither can this Court supply a casus omissus in a treaty, any more than in a law. We are to find out the intention of the parties, by just rules of interpretation, applied to the subject matter; and having found that, our duty is to follow it, so far as it goes, and to stop where that stops - whatever may be the imperfections or difficulties which it leaves behind. ${ }^{25}$

This interpretative reliance applies not only when the treaty itself is before the Court, but also when the treaty is used to help interpret an implementing statute of Congress. So, for example, in interpreting the Carriage of Goods by Sea Act, Justice Whittaker of the Supreme Court noted:

The legislative history of the Act shows that it was lifted almost bodily from the Hague Rules of 1921 , as amended by the Brussels Convention of 1924, 51 Stat. 233. The effort of those Rules was to establish uniform ocean bills of lading to govern the rights and liabilities of carriers and shippers inter se in international trade. Those Rules do not advert to stevedores or agents of a carrier. ${ }^{26}$

When determining a rule of international customary law, U.S. courts tend to collect rather diverse evidences showing the rule

23. 457 U.S. 176, 184-185 (1982).

24. Id. at 180 .

25. The Amiable Isabella, 19 U.S. (6 Wheaton) 1,71 (1821).

26. Herd \& Co. v. Krawill Machinery Corp., 359 U.S. 297, 301 (1959); also see National Wildlife Federation v. Costle, 629 F.2d 118, 121-122 (D.C. Cir. 1980). 
without putting the evidences in any particular order of priority. ${ }^{27}$ This same eclectic tendency is apparent in the interpretation of international maritime conventions by U.S. judges. For example, in United States $v$. Maine, the Supreme Court reviewed the question of whether Nantucket Sound "qualifies as 'internal waters' of the Commonwealth of Massachusetts rather than partly territorial sea and partly high seas" as contended by the United States. ${ }^{28}$ For the Court, Justice Stevens wrote:

This Court has consistently followed principles of international law in fixing the coastline of the United States. We have relied in particular on the Convention on the Territorial Sea and Contiguous Zone, [1958] 15 U.S.T. 1607, T.I.A.S. No. 5639. The Convention provides that the sovereignty of a state extends to "internal waters." Art. 1. The Convention also contains a set of rules delimiting those waters ... Of importance to this case, the Convention also includes as a state's "internal waters" those waters enclosed in "bays" as defined in Article 7. Most of the rules in this Article identify the criteria for defining "juridical bays," but Article 7(6) further includes as "bays" "so-called 'historic' bays" $\ldots . .^{29}$

Massachusetts relied on the Convention's "historic bay" provision to argue that Nantucket Sound was within its internal waters. However, the Convention nowhere defined "historic bay."30 In defining "historic bay" and deciding against Massachusetts, the Court first turned to a United Nations study. ${ }^{31}$ The judgment then looked to maritime practice in the seventeenth and eighteenth centuries as reported in treatises by Brownlie and Blum, ${ }^{32}$ to the judgment of the International Court of Justice in the Fisheries Case, ${ }^{33}$ to an Indian decision, ${ }^{34}$ and finally to claims based on the exploitation of marine resources by, e.g., Australia, Mexico, Columbia, and Algeria. $^{35}$ These evidences demonstrated that for Massachusetts' claim to succeed, the state needed to demonstrate an "effective occupation" of the historic bay "perfected no later than the latter half of

27. Janis, supra note 1 , at 83-87.

28. 475 U.S. 89,90 (1986).

29. Id. at 93-94.

30. Id. at 94 .

31. Id. at 94-96; Juridical Regime of Historic Waters, Including Historical Bays, [1962] 2 Y.B. Int ' L. Comm'n. 1, U.N. Doc. A/CN.4/143 (1962).

32. 475 U.S. 89, 96-97.

33. Id. at 99; 1951 I.C.J. Reports 116.

34. 475 U.S. 89, 99-100; Annakumaru Pillai v. Muthupayal, 27 Indian L.R. Madras 551 (1903).

35. 475 U.S. $89,100$. 
the 18th century," a proof the state was unable to muster. ${ }^{36}$

Unscientific as it was, the Massachusetts case's employment of diverse international evidences constitutes a much better than average example of an examination of international law by U.S. courts interpreting international maritime conventions. Much more typical is the proof of rules respecting freedom of navigation on the high seas in United States $v$. Rubies, a judgment of the U.S. Ninth Circuit Court of Appeals. ${ }^{37}$ In Rubies there was only a passing reference made to the 1958 Geneva Conventions on the High Seas and on the Territorial Sea and Contiguous Zone. ${ }^{38}$ Relying mostly on U.S. case law, the Court looked only cursorily at treatises by Oppenheim, Brownlie and Myers and at a single foreign case. ${ }^{39}$ Similarly, in United States $v$. Dominguez, rules respecting changes of a ship's nationality at sea were interpreted in a mere three sentences referring to Oppenheim, the 1958 Convention on the High Seas, and a foreign case. ${ }^{40}$ Even more abrupt was United States $v$. Smith, where the First Circuit determined that the United States had "authority to treat stateless vessels as if they were its own" by simply citing the 1958 High Seas Convention. ${ }^{41}$ The Smith court concluded that "the United States has enacted the customary law of the sea by ratifying the Convention." 42

This is not to say that U.S. courts do not regularly rely upon international maritime conventions. In one of the most frequently cited maritime cases, United States $v$. California, ${ }^{43}$ the Supreme Court went to great length to demonstrate that "the meaning of 'inland waters' in the Submerged Lands Act should conform to the Convention on the Territorial Sea and Contiguous Zone."44 The Court rejected the U.S. government's position that "we must ignore the Convention on the Territorial Sea and the Contiguous Zone in performing our duty of giving content to 'inland waters' as used in the Submerged Lands Act, and must restrict ourselves to determining what our decision would have been had the question been presented to us for decision on May 22, 1953, the date of enactment."45 Instead, the court held:

Had Congress wished us simply to rubber-stamp the statements of the State Department as to its policy in 1953, it

36. Id. at 93-105.

37. 612 F.2d 397 (9th Cir. 1979).

38. Id. at $402-403$.

39. Ibid; Molvan v. Attorney General for Palestine, 1948, A.C. 351.

40. 604 F.2d 304, 308 (4th Cir. 1979), cert. denied 444 U.S. 1014 (1980).

41. 680 F.2d 255, 258 (1st Cir. 1982).

42. Ibid.

43. 381 U.S. 139 (1965).

44. Id. at 161-167.

45. Id. at 164 . 
could readily have done so itself. It is our opinion that we best fill our responsibility of giving content to the words which Congress employed by adopting the best and most workable definitions available. The Convention on the Territorial Sea and the Contiguous Zone, approved by the Senate and ratified by the President, provides such definitions. This establishes a single coastline for both the administration of the Submerged Lands Act and the conduct of our future international relations (barring an unexpected change in the rules, established by the Convention). Furthermore the comprehensiveness of the Convention provides answers to many of the lesser problems related to coastlines which, absent the convention, would be most troublesome. ${ }^{46}$

One of the recurrent problems involving interpretation of international maritime conventions in the United States is fixing the relationship between these obligations and U.S. municipal law. Article VI(2) of the Constitution makes both treaties and Federal law "the supreme Law of the Land" but does not give one or the other priority. The U.S. courts will in the first place attempt to reconcile apparently conflicting laws and treaty rules: "[A]n act of Congress ought never to be construed to violate the law of nations, if any other possible construction remains."47 If this is not possible then the provision later-in-time controls:

By the Constitution a treaty is placed on the same footing, and made of like obligation, with an act of legislation. Both are declared by that instrument to be the supreme law of the land, and no superior efficacy is given to either over the other. When the two relate to the same subject, the courts will always endeavor to construe them so as to give effect to both; if that can be done without violating the language of either; but if the two are inconsistent, the one last in date will control the other, provided always the stipulation of the treaty on the subject is self-executing. ${ }^{48}$ '

So, in Cook $v$. United States, the Supreme Court held that the Treaty of May 22, 1924 with Great Britain controlled the Tariff Act of 1922.49 In 1930, the U.S. Coast Guard boarded a British vessel, the

46. Id. at 165. For other cases relying on California and the Convention on the Territorial Sea and Contiguous Zone, see United States v. Louisiana, 389 U.S. 155, 158 (1967); United States v. Alaska, 422 U.S. 184, 188 (1975); Texas v. Louisiana, 426 U.S. 465, 468-69 (1976); United States v. California, 447 U.S. 1, 5 (1980); United States v. Maine, 475 U.S. 89, 93 (1986). For the Convention on the Continental Shelf, see Treasure Salvors v. Unidentified Wrecked, Etc., 569 F.2d 330, 338-340 (5th Cir. 1978).

47. Murray v. The Charming Betsy, 6 U.S. (2 Cranch) 64, 118 (1804).

48. Whitney v. Robertson, 124 U.S. 190, 194 (1887).

49. 288 U.S. 102 (1933). 
Mazel Tov, sorne eleven-and-a-half miles and more than one hour from the coast of Massachusetts and discovered unmanifested liquor. The vessel was brought to Providence and a penalty assessed for not manifesting the liquor; the Mazel Tov was seized. Cook, the master and bailee of the boat, argued that it had been arrested outside the jurisdiction of the United States. ${ }^{50}$ The 1924 Treaty, inter alia, limited U.S. search-and-seizure rights over British vessels to distances no more "than can be traversed in one hour by the vessel suspected of endeavoring to commit the offense." 51 Although the 1922 Act permitted seizures up to twelve miles off the U.S. coast, ${ }^{52}$ the court, in an opinion by Justice Brandeis, ruled:

The Treaty, being later in date than the Act of 1922, superseded, so far as inconsistent with the terms of the Act, the authority which had been conferred by $\S 581$ upon officers of the Coast Guard to board, search and seize beyond our territorial waters... For in a strict sense the Treaty was self-executing, in that no legislation was necessary to authorize executive action pursuant to its provisions. ${ }^{33}$

Furthermore:

The Treaty was not abrogated by re-enacting $\S \mathbf{5 8 1}$ in the Tariff Act of 1930 in the identical terms of the Act of 1922. A treaty will not be deemed to have been abrogated or modified by a later statute unless such purpose on the part of Congress has been clearly expressed ... Here, the contrary appears. The committee reports and the debates upon the Act of 1930, like the re-enacted section itself, make no reference to the Treaty of 1924 . Any doubt as to the construction of the section should be deemed resolved by the consistent departmental practice existing before its re-enactment . . . No change, in this respect, was made either by the Department of the Treasury or the Department of Justice after the Tariff Act of 1930.54

The later-in-time rule and the Cook case have figured in modern cases. ${ }^{55}$ In United States $v$. Cadena: "The [High Seas] Convention of 1958, if applicable, supersedes prior domestic law to the contrary, Cook v. United States."56 In Cadena, the Court refused to apply the treaty because the foreign countries involved, Canada and Colombia, were not parties to the convention: "Even if individuals have stand-

50. Id. at 108 .

51. Id. at 111 .

52. Id. at 107 .

53. Id. at 118-119.

54. Id. at 119-120.

55. See United States v. Ray, 423 F.2d 16, 21 (5th Cir. 1970).

56. 585 F.2d 1252, 1260 (5th Cir. 1978). 
ing to raise treaty violations, their personal rights are derived from the rights of a signatory state." 57 In United States $v$. MYS Prokofyeva, a U.S. district court held that a 1976 statute was quite "apparent" in its abrogation of Article 7 of the 1958 Convention on Fishing and Conservation of the Living Resources of the High Seas..$^{58}$

However, the later-in-time rule does not apply to conflicts between international maritime conventions and state law. The Constitution's Supremacy Clause has been uniformally held to preempt state statutes of no matter what date. ${ }^{59}$ Interestingly, the supremacy of international agreements over state law even extends to agreements not submitted to the Senate for its advice and consent under Article II of the Constitution. As Justice Sutherland held for the Supreme Court in 1937:

A treaty signifies "a compact made between two or more independent nations with a view to the public welfare." Altman \& Co. v. United States, 224 U.S. 583, 600. But an international compact, as this was, is not always a treaty which requires the participation of the Senate. There are many such compacts, of which a protocol, a modus vivendi, a postal convention, and agreements like that now under consideration are illustrations....

Plainly, the external powers of the United States are to be exercised without regard to state laws or policies. The supremacy of a treaty in this respect has been recognized from the beginning. Mr. Madison, in the Virginia Convention, said that if a treaty does not supersede existing state laws, as far as they contravene its operation, the treaty would be ineffective. "To counteract it by the supremacy of the state laws, would bring on the Union the just charge of national perfidy, and involve us in war." ... In respect of all international negotiations and compacts, and in respect of our foreign relations generally, state lines disappear." 60

The U.S. courts will also apply and interpret international maritime conventions when ordinary choice of law principles indicate that foreign law should apply to the transaction and that foreign law incorporates an international agreement. So, in Alkmeon Naviera, S.A. v. $M / V$ Marina $L$, the U.S. Ninth Circuit Court of Appeals dealt with a collision case involving two ships of Greek registry:61

57. Id. at 1261.

58. 17 U.S.T. 139, T.I.A.S. No. 5969; 536 F.Supp. 793, 796-797 (D. Alaska 1982).

59. Missouri v. Holland, 252 U.S. 416 (1920); Asakura v. Seattle; 265 U.S. 332 (1924).

60. United States v. Belmont, 301 U.S. 324, 330-331 (1937).

61. 633 F.2d 789, (9th Cir. 1980). 
In collisions occurring on the high seas, general maritime law usually applies ... Where, however, both ships are of the same registry, the law of the common flag applies ... This does not mean, however, that our task becomes one of determining and applying foreign law; Greece, in common with most nations involved in commercial shipping is a party to the 1960 Safety of Life at Sea Convention. ${ }^{62}$

Furthermore, one treaty may be used to interpret another. So, for example, the multilateral convention on the Territorial Sea and the Contiguous Zone, inter alia, was employed by the Second Circuit in United States v. Quemener to interpret a bilateral agreement between the United States and Great Britain. ${ }^{63}$ The bilateral treaty permitted the United States to interdict vessels within 150 miles of the United States and the question was whether that distance was to be measured only from the mainland or also from islands. The Second Circuit turned to U.S. case law, ${ }^{64}$ publicists such as Wheaton and Jessup, ${ }^{65}$ and U.S. and British diplomatic practice, ${ }^{66}$ to support the rule of measuring from islands.

Finally, this position is supported by reference to a number of international treaties. Most significant, the Convention on the Territorial Sea and the Contiguous Zone, which appellants point to as providing the source for a definition of "coastline," specifically confirms that islands possess independent coasts or coastlines . . . " 1 . An island is a naturally-formed area of land, surrounded by water, which is above water at high-tide. 2. The Territorial Sea of an island is measured in accordance with these articles.") ${ }^{67}$

Finally, U.S. courts have interpreted international maritime conventions to discover customary international law. The Fifth Circuit Court of Appeals in United States v. Williams refused to directly apply the Convention on the High Seas to the facts of the case because Panama, the flag state of a boarded vessel, was not a party to the Convention. ${ }^{68}$ But, noting that the High Seas Convention was "a codification of international law," and that Panama had consented to the boarding:

We do not think that the Convention was meant to protect the privacy of those on board but rather the Treaty is a means to protect the national interest implicit in freedom of

62. Id. at 793 .

63. 789 F.2d 145 (2d Cir. 1986).

64. Id. at 151.

65. Id. at 151-52.

66. Id. at $152-53$.

67. Id. at 153.

68. 589 F.2d 210, 212 (5th Cir. 1979). 
the seas - an interest that the United States has held dear throughout its history. ${ }^{69}$

In a similar case, the Fourth Circuit followed Williams and held that Panama had waived what the Court called Panama's " 'article 6' rights under common law."70

69. Ibid.

70. United States v. Pena-Jessie, 763 F.2d 618 (4th Cir. 1985). 